Article

\title{
Life Cycle Blue and Grey Water in the Supply Chain of China's Apparel Manufacturing
}

\author{
Ao Liu ${ }^{1}$, Aixi Han ${ }^{1}$ and Li Chai ${ }^{1,2, *(D)}$ \\ 1 International College Beijing, China Agricultural University, Beijing 100083, China; \\ 2018314060506@cau.edu.cn (A.L.); 2017314060118@cau.edu.cn (A.H.) \\ 2 College of Economics and Management, China Agricultural University, Beijing 100083, China \\ * Correspondence: chaili@cau.edu.cn
}

check for updates

Citation: Liu, A.; Han, A.; Chai, L. Life Cycle Blue and Grey Water in the Supply Chain of China's Apparel Manufacturing. Processes 2021, 9 , 1212. https://doi.org/10.3390/ pr9071212

Academic Editors: Anna Trubetskaya and Lara Carvalho

Received: 20 June 2021

Accepted: 12 July 2021

Published: 15 July 2021

Publisher's Note: MDPI stays neutral with regard to jurisdictional claims in published maps and institutional affiliations.

Copyright: (c) 2021 by the authors. Licensee MDPI, Basel, Switzerland. This article is an open access article distributed under the terms and conditions of the Creative Commons Attribution (CC BY) license (https:// creativecommons.org/licenses/by/ $4.0 /)$.

\begin{abstract}
Apparel manufacturing involves high water consumption and heavy water pollution in its supply chain, e.g., planting cotton, producing chemical fibers, and dyeing. This study employs a multi-regional input-output (MRIO) model to (1) assess the life cycle of blue and grey water (chemical oxygen demand (COD) specific) of China's apparel manufacturing; (2) reveal the hidden linkage among sectors and regions in the whole supply chain; and (3) identify the key regions and upstream sectors with the most water consumption and heaviest water pollution. We found that the agricultural sector (i.e., planting fiber crops) is responsible for primary water consumption and water pollution. In addition, different provinces assume different production roles. Guangdong is a major output province in apparel manufacturing. However, its economic output is contributed to by other regions, such as blue water from Xinjiang and Jiangsu and grey water from Hebei and Shandong. Our research reveals the significance of taking an inter-regional perspective on water resource issues throughout the supply chain in apparel manufacturing. The sustainable development of China's apparel manufacturing relies on improving water-use efficiency and reasonable industrial layout. The results are of significance and informative for policymakers to build a water-sustainable apparel industry.
\end{abstract}

Keywords: MRIO; blue water; grey water; COD; apparel manufacturing; life cycle

\section{Introduction}

Water is an essential natural resource for human society, and it is significantly affected by human activities [1]. Globally, water use in manufacturing has caused severe environmental problems, such as water shortages and water pollution [2]. Apparel manufacturing is particularly serious in terms of water consumption and water pollution. As a major material in making apparel, cotton cultivation is water intensive, accounting for approximately $3 \%$ of global agricultural water use [3]. The intermediate processing sector of the apparel supply chain lies in the textile industry, one of the most water-polluting sectors [4]. The water use of the textile process not only causes serious groundwater depletion [5], but also discharges a large amount of toxic chemicals, causing serious water pollution issues $[6,7]$.

As the biggest exporter of textile products worldwide [8], China has faced problems of high water consumption and heavy water pollution [9]. The textile industry ranked third among the largest dischargers of wastewater in 2015 [10]. As a water-intensive industry, achieving sustainable water resources management is a huge challenge for China's apparel industry [11]. Li et al. (2021) [9] pointed out that the two ways to achieve water sustainability are reducing water consumption and water pollution.

To reveal the pressure on the environment caused by apparel manufacturing, quantifying the supply chain's water consumption and water pollution is necessary. Chapagain et al. (2006) [12] estimated that global consumption of cotton, one of the primary materials, requires $256 \mathrm{Gm}^{3}$ of water per year. Kazan et al. (2020) [13] concluded that pesticide and synthetic fertilizer usage during cotton cultivation are the major factors increasing 
environmental impacts. Liu et al. (2020) [14] evaluated the environmental impact of different melange yarns, seeking opportunities for improvement from the manufacturer's perspective. Many studies have explored the potential environmental impacts of apparel manufacturing from the perspective of various raw materials $[13,15,16]$, different processes and technologies [17], and diverse products [14,18,19]. Those studies employed process-based model from a bottom-up perspective to investigate the direct water use in each process and to assess the aggregated impacts. While bottom-up approaches have the advantage in analyzing product details, they lack comprehensive coverage of the industry chains, leading to underestimations of the overall environmental effect [20].

In the context of regional trade development, regions may be cast in different roles, according to their comparative advantages. As a basis for managing water resources and mitigating water scarcity in different economic sectors, input-output (IO) models are also widely used to account for the life cycle of water resources [21]. Many scholars have used input-output models for accounting in the environmental domain [22-24]. Water use is a complex process involving flows among different economic sectors, which causes complex interactions within the whole economic system [25]. The single IO model can hardly reveal the inherent relationship among sectors, which may impede the analysis of the system's metabolic performance and water-use structure [26,27]. Developed based on the IO model, the multi-regional input-output (MRIO) model unites direct and indirect flows associated with economic activities and allows such links along the complete international or interregional supply chains of all products and services [28,29]. This model has been applied to various studies concentrated on environmental issues, including material use [30-32], greenhouse gas emissions [33,34], and land [35] and water resources [36]. Therefore, the MRIO model can be used to examine the water impacts and reveal the hidden linkages among regions and sectors in the supply chain of apparel manufacturing.

In order to mitigate the negative impacts of apparel manufacturing on water resources, identifying the interregional and intersectoral water transfer is essential for regional and industrial sustainable development. This study employs an MRIO model to assess China's apparel manufacturing's life cycle water consumption and pollution. The sectoral transfer and the spatial flow patterns of water are also analyzed by using this model. The results can help policymakers develop targeted recommendations by identifying the key regions and upstream sectors with the most water consumption and heaviest water pollution.

\section{Materials and Methods}

Water footprints, as an indicator proposed by Hoekstra et al., [37], have been widely used to assess the water impacts of human activities [24,38,39]. There are three components in a water footprint, i.e., green, blue, and grey water. They respectively indicate the occupation of the precipitation resource, freshwater resource (i.e., groundwater and surface water) and water quality. Due to data availability, this study does not consider green water. In this study, both water depletion (blue water) and pollution (grey water) are considered to examine the impacts on water resources. Many types of water pollutants are involved in the supply chain of apparel manufacturing, including chemical oxygen demand (COD), amino-nitrogen, heavy metals, etc. In this study, we select COD as the representative of water pollutants because (1) COD is a main monitoring water pollutant by China's government, and therefore its discharge data are available publicly; and (2) COD is a major water pollutant discharged from the industrial sector and severely degrades China's water quality $[40,41]$.

COD-specific grey water refers to the freshwater amount required to dilute the discharged COD to a safe concentration, set by regulations. It quantifies the impacts of water pollution discharge on water resources. It can be calculated using the following equation:

$$
d w_{\text {grey }}=L /\left(C_{\max }-C_{\text {nat }}\right)
$$

where $d w_{\text {grey }}$ is grey water; $L$ is the discharge amount of pollutant to environment; $C_{\max }$ is the maximum permissible concentration for pollutant in the water body set by China's 
quality standard for surface water $\left(20 \mathrm{mg} / \mathrm{L}\right.$ for COD); and $C_{n a t}$ is the concentration of pollutant $\mathrm{p}$ in the natural water body, which is usually assumed to be zero.

The multi-regional input-output (MRIO) model is employed in this study to investigate the life-cycle of blue and grey water in apparel manufacturing. The MRIO model is widely used to assess the virtual water flows among sectors and regions [39,42].

The life cycle of blue (grey) water consists of indirect and direct components. The indirect component can be calculated, using the following equation:

$$
i d w_{i}^{r, s}=x_{i}^{r, s} \cdot d w_{i}^{r, s}+\sum_{s=1} \sum_{j=1}\left(x_{i}^{r, s} \cdot b_{i, j}^{r, s} \cdot d w_{j}^{r, s}\right)
$$

where $i d w_{i}^{r, s}$ indicates the indirect blue (grey) water use by sector $i$ of region $r$ in the supply chain of region $s^{\prime}$ apparel manufacturing; $d w$ is the direct water use; $x_{i}^{r, s}$ refers to the demand of sector $i$ of region $r$ in the supply chain of region $s^{\prime}$ apparel manufacturing; and $b_{i, j}^{r, s}$ is the complete consumption coefficient of sector $i$ in region $r$ by sector $j$ in region $s$.

Therefore, Equation (2) can be written as the following matrix equation:

$$
\mathrm{IDW}=(\mathrm{X}+\mathrm{B} \times \mathrm{X}) \cdot \times \mathrm{DW}
$$

The complete consumption coefficient matrix B can be calculated as follows:

$$
\mathrm{B}=(\mathrm{I}-\mathrm{A})^{-1}-\mathrm{I}
$$

where I is an identify matrix; and A is the direct consumption matrix, which can be obtained from the MRIO table.

Equation (3) can be re-written as the following:

$$
\mathrm{IDW}=(\mathrm{I}-\mathrm{A})^{-1} \mathrm{X} . \times \mathrm{DW}
$$

The life cycle of blue (grey) water use ( $\left.L W_{\text {apparel }}\right)$ can be assessed by summing up the indirect component $\left(i d w_{i}^{r, s}\right)$ and the direct component $\left(d w_{\text {apparel }}^{s}\right)$ :

$$
L W_{\text {apparel }}=\sum_{s=1}\left(\sum_{r=1} \sum_{i=1} i d w_{i}^{r, s}+d w_{\text {apparel }}^{s}\right)
$$

The life cycle of water use originating from region $r\left(L W_{a p p a r e l}^{r}\right)$ can be estimated as follows:

$$
L W_{\text {apparel }}^{r}=\sum_{s=1}\left(\sum_{i=1} i d w_{i}^{r, s}+d w_{\text {apparel }}^{s}\right)
$$

The life cycle of water use originating from sector $i\left(L W_{i, \text { apparel }}\right)$ can be estimated as follows:

$$
L W_{i, \text { apparel }}=\sum_{s=1}\left(\sum_{r=1} i d w_{i}^{r, s}+d w_{\text {apparel }}^{s}\right)
$$

The MRIO table of 2015 in China is obtained from the previous study (32 regions and 42 sectors in each region) [43]. The output value (unit is CNY) of apparel manufacturing in each region is obtained from the MRIO table. The sector-wise data of water consumption and COD discharge are obtained from Annual Statistic Report on Environment in China and China Statistical Yearbook on Environment [10].

\section{Results}

\subsection{Water Transfer in the Apparel Manufacturing}

As shown in Figure 1, China's apparel manufacturing consumed $30.50 \mathrm{Gm}^{3}$ of blue water and discharged $114.36 \mathrm{Gm}^{3}$ of grey water in its life-cycle supply chain in 2015. Blue water refers to the water consumption in the apparel industry, and the water pollution is indicated by grey water (COD-specific). Grey water, once again, is not the same as "wastewater" but indicates the freshwater that is required to dilute the polluted water to a 
safe concentration. Grey water quantifies the impact of water pollutants (COD) on freshwater, and it may be more than water consumption when COD is discharged at a very high concentration. The results show that grey water was 4.58 times the amount of blue water, indicating that the water pollution induced by apparel industry is especially noteworthy.

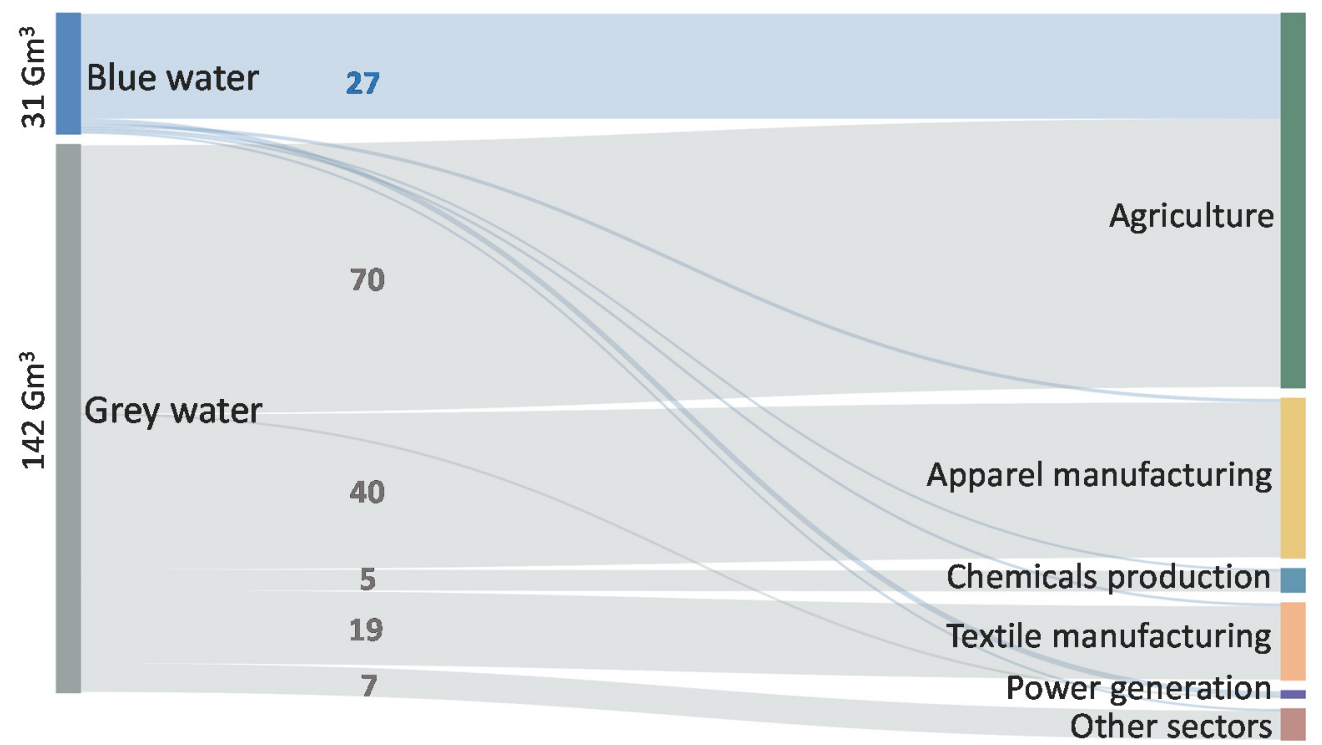

Figure 1. The sector-wise blue and grey water use in the supply chain of China's apparel manufacturing in 2015.

The apparel industry's supply chain is categorized into six sectors: agriculture, apparel manufacturing, chemicals production, textile manufacturing, power generation, and other sectors. Most of the blue water $\left(27.23 \mathrm{Gm}^{3}\right)$ was consumed by the agriculture sector, accounting for $87.43 \%$ of the total, as the fiber plants (e.g., cotton) are water-intensive crops. The following sectors were power generation and textile manufacturing, consuming only $1.42 \mathrm{Gm}^{3}$ and $0.72 \mathrm{Gm}^{3}$ of blue water. The other three sectors contributed only $1.74 \mathrm{Gm}^{3}$ of blue water consumption in total.

In the discharge of grey water, the agriculture sector is still the largest contributor; $49.11 \%$ of the total water pollution (i.e., COD pollution) was from planting raw materials for apparel manufacturing, which generated $69.65 \mathrm{Gm}^{3}$ of grey water. The second largest sector discharging grey water is the apparel manufacturing sector, which generated $40.2 \mathrm{Gm}^{3}$ of industrial grey water and occupied $28.34 \%$ of the total. For the other sectors in the supply chain of China's apparel manufacturing and textile manufacturing, other sectors and chemicals production sectors discharged $18.99 \mathrm{Gm}^{3}, 7.37 \mathrm{Gm}^{3}$, and $5.40 \mathrm{Gm}^{3}$ grey water. In total, they account for $22.40 \%$ of the total grey water.

\subsection{Output Value, Water Consumption and Water Pollution at the Provincial Level}

Figure 2 illustrates the total output value of the apparel manufacturing in each province of China and the blue and grey water consumed behind this industry. Figure $2 \mathrm{a}$ shows an uneven distribution of China's apparel manufacturing, with a high output value concentrated in the eastern coastal regions. Overall, the apparel manufacturing in China generated a total economic value of CNY 3981.42 billion, among which Guangdong (CNY 875.90 billion), Jiangsu (CNY 545.60 billion) and Fujian (CNY 493.70 billion) are the top three provinces, featuring $22.00 \%, 13.70 \%$ and $12.40 \%$ of the total value, respectively. 
b. blue water

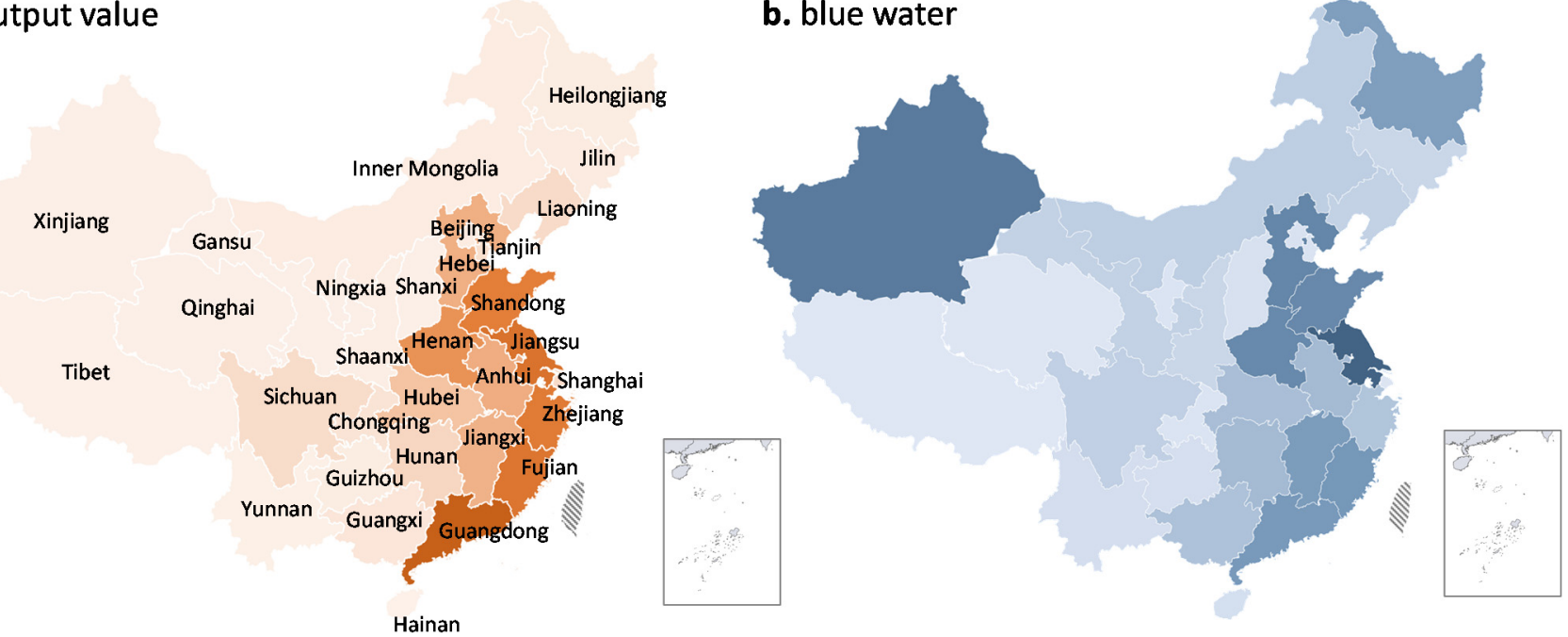

c. grey water
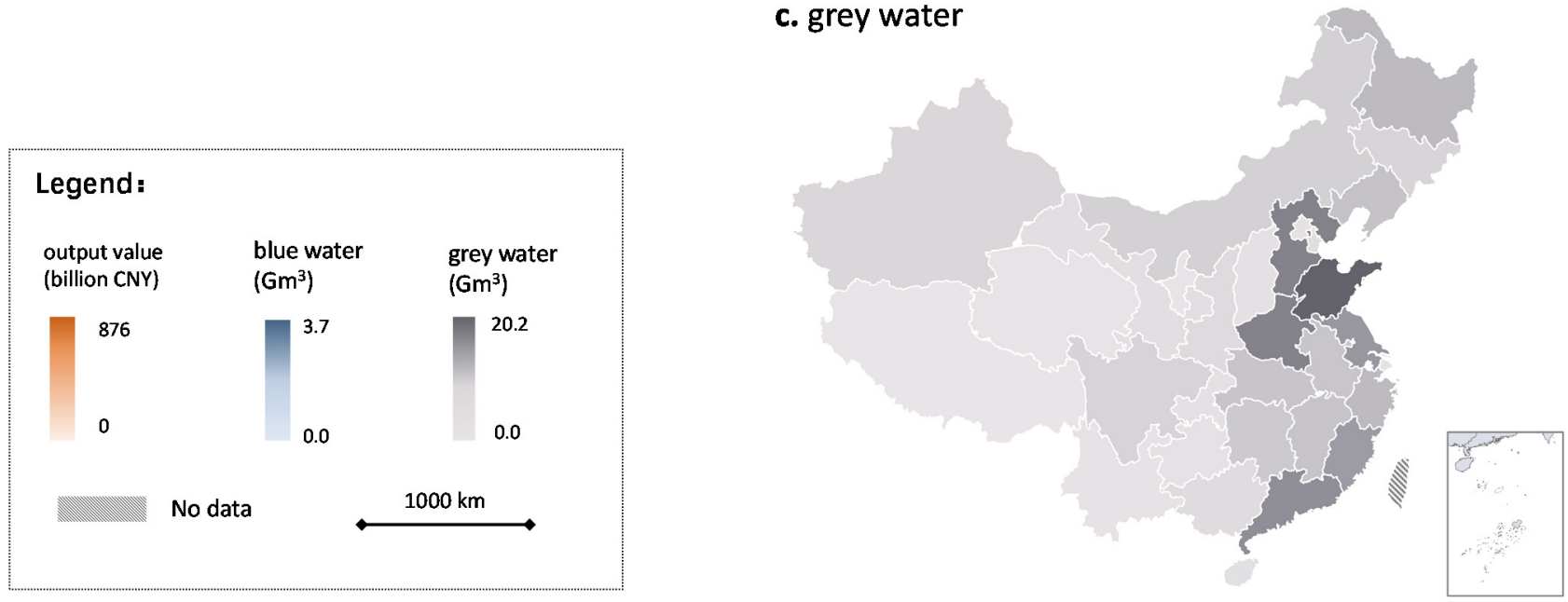

Figure 2. The output value (a), blue water (b), and grey water (c) in the supply chain of China's apparel manufacturing.

Figure $2 \mathrm{~b}$ reveals the distribution of blue water consumption in apparel manufacturing. Except for Xinjiang, the regions with high blue water consumption are mainly distributed in the eastern and southeastern regions. Jiangsu, Xinjiang and Hebei are the provinces with the highest blue water consumption, consuming $3.71 \mathrm{Gm}^{3}, 2.91 \mathrm{Gm}^{3}$ and $2.53 \mathrm{Gm}^{3}$, respectively. Their blue water consumption accounted for $30.00 \%$ of the whole $30.50 \mathrm{Gm}^{3}$ of blue water in China. As the major cotton producers, these provinces consumed a large amount of blue water.

As shown in Figure 2c, the grey water was mainly discharged from the eastern coastal regions. China's apparel manufacturing discharged a total of $114.36 \mathrm{Gm}^{3}$ of greywater in 2015, with Shandong $\left(20.17 \mathrm{Gm}^{3}\right)$, Hebei $\left(13.39 \mathrm{Gm}^{3}\right)$ and Henan $\left(13.46 \mathrm{Gm}^{3}\right)$ generating the most, accounting for $17.66 \%, 11.71 \%$ and $11.80 \%$ of the total, respectively. As for Shandong, a vital textile production base in China, with high water consumption and high pollution characteristics, the textile industry discharged a large amount of grey water.

Overall, China's apparel manufacturing is mainly located in the eastern and coastal regions, which have become important distribution centers for apparel products by their well-developed infrastructure and convenient transportation. While the apparel industry brings high output value, the related raw material supply areas also consume high water consumption and discharge water pollution, such as Xinjiang, from where cotton is supplied, and Shandong, from where textiles are supplied. This brings an environmental burden to the local area. 


\subsection{Spatial Transfer of Blue and Grey Water in China's Apparel Manufacturing}

Figure 3 illustrates the inter-provincial flows of blue water and grey water among 31 regions in China in 2015. Figure 3a shows that Xinjiang and Heilongjiang were the major blue water exporters, sending out $2.66 \mathrm{Gm}^{3}$ and $1.71 \mathrm{Gm}^{3}$ of blue water to other provinces, which feature $18.51 \%$ and $11.91 \%$ of the overall flows. Meanwhile, the blue water inflow to those provinces was very limited (only 0.01 and $0.06 \mathrm{Gm}^{3}$ ). Therefore, it can be found that these two provinces take the essential task of blue water exporting in apparel manufacturing. On the other hand, Guangdong was the largest blue water receiver, which received $3.01 \mathrm{Gm}^{3}$ of blue water, accounting for $20.94 \%$ of the whole. The following receivers were Henan $\left(1.61 \mathrm{Gm}^{3}\right)$ and Zhejiang $\left(1.46 \mathrm{Gm}^{3}\right)$. Among all the identified transfers, the flow of Xinjiang-Guangdong, -Henan, and -Shandong had the largest amount, with $0.53,0.39$ and $0.38 \mathrm{Gm}^{3}$ of transferred blue water, respectively. This indicates that Xinjiang is an essential supplier in the supply chain of China's apparel manufacturing, especially for the apparel manufacturing in Guangdong, Henan and Zhejiang.

a. blue water

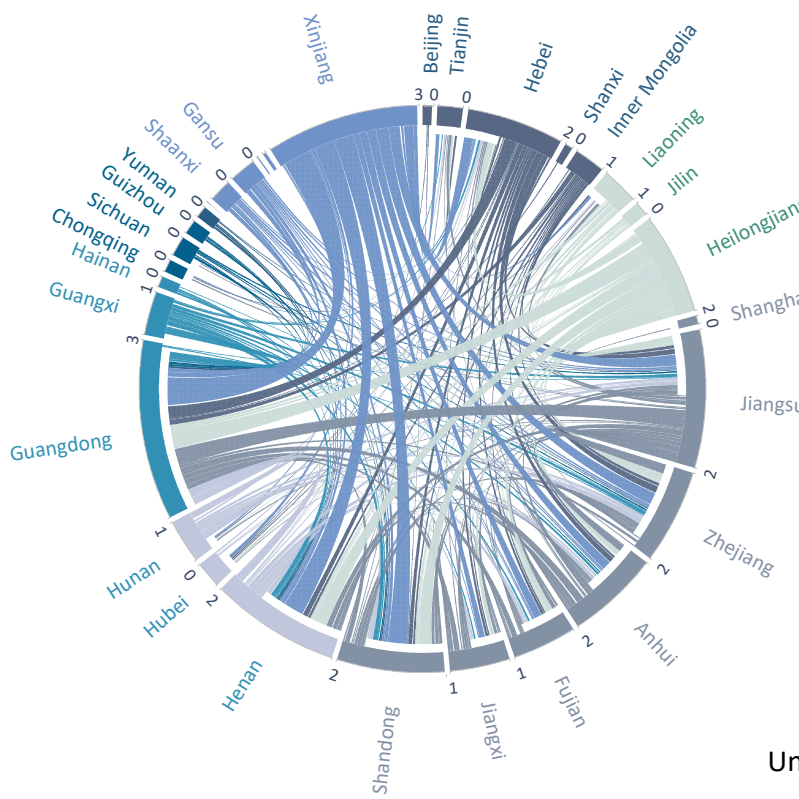

b. grey water

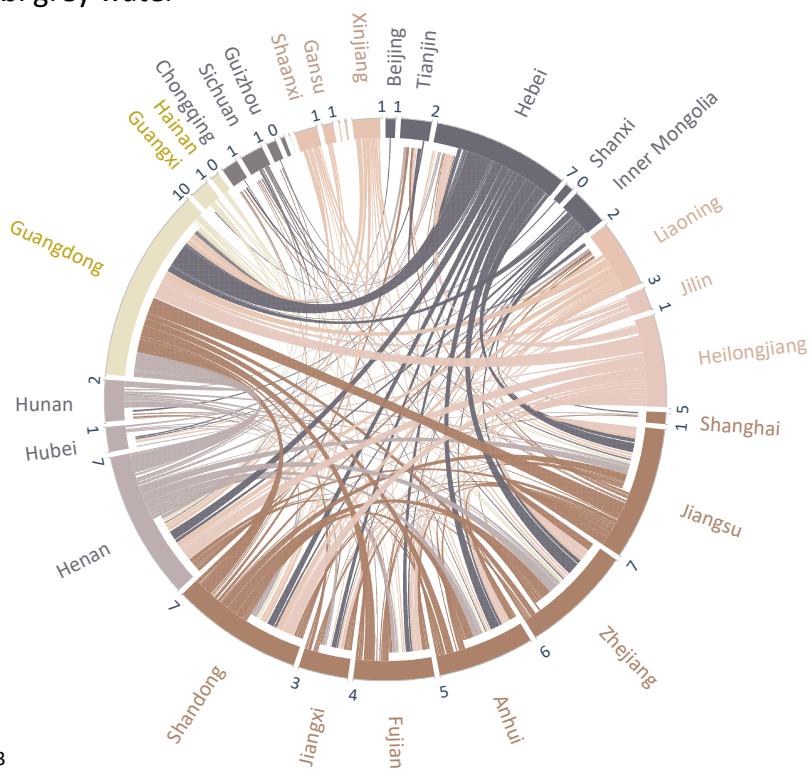

Figure 3. Blue (a) and grey (b) water flows among 31 regions in China's apparel manufacturing in 2015.

The spatial transfer pattern of grey water in China's apparel manufacturing in 2015 is shown in Figure $3 \mathrm{~b}$. The total grey water flows in the apparel supply chain were $39.55 \mathrm{Gm}^{3}$. The largest grey water flow was from Hebei to Guangdong $\left(1.31 \mathrm{Gm}^{3}\right)$, following by HenanGuangdong $\left(0.94 \mathrm{Gm}^{3}\right)$, Heilongjiang-Guangdong $\left(0.90 \mathrm{Gm}^{3}\right)$ and Jiangsu-Guangdong $\left(0.90 \mathrm{Gm}^{3}\right)$. Guangdong was the largest grey water receiver with a net inflow of $9.13 \mathrm{Gm}^{3}$. The following top receivers were Zhejiang $\left(4.55 \mathrm{Gm}^{3}\right)$, Henan $\left(3.73 \mathrm{Gm}^{3}\right)$ and Jiangsu $\left(3.51 \mathrm{Gm}^{3}\right)$. In contrast, Hebei contributed the most grey water $\left(5.53 \mathrm{Gm}^{3}\right)$, occupying $14 \%$ of the total. This is following by Heilongiiang $\left(4.42 \mathrm{Gm}^{3}\right)$, Henan $\left(3.72 \mathrm{Gm}^{3}\right)$ and Shandong $\left(3.42 \mathrm{Gm}^{3}\right)$.

As the largest recipient of blue water and grey water in China's apparel manufacturing, Guangdong received a large amount of blue water from other regions and transferred massive grey water to the remaining provinces. Although Guangdong was the largest producer of apparel manufacturing in China, its industrial development heavily depended on other regions' contributions. The major blue water contributors are Xinjiang, Heilongiiang, and Jiangsu. They exported $1.21 \mathrm{Gm}^{3}$ in total, occupying $40.22 \%$ of the blue water transfer in Guangdong. On the other hand, the major grey water generators are Hebei, Henan and Heilongjiang. They discharged $3.15 \mathrm{Gm}^{3}$ of grey water, with $34.52 \%$ of Guangdong's total grey water transferred. Thus, identifying the source is the key point of solving the water 
consumption and water pollution problems in apparel manufacturing. For the major blue water contributors, such as Xinjiang and Heilongjiang, their water consumption should be strictly controlled to avoid local water shortages. In addition, for the major grey water producers, such as Hebei and Heilongjiang, stricter pollution discharge standards should be implemented to control water pollution problems.

\section{Discussion}

From the perspective of the entire supply chain of apparel manufacturing in China, the agricultural sector is the major water consumption and water pollution sector. It is mainly responsible for providing raw materials for its downstream textile industry, such as cotton cultivation. Cotton is a water-intensive crop that consumes a large amount of water in its growth. China is a sizeable cotton-producing country. The cotton planting area is 5.53 million $\mathrm{hm}^{2}$, accounting for $15 \%$ of the global cotton planting area [44]. The main cottonproducing areas in China are located in the Yellow River Basin, the Yangtze River Basin, and the inland northwest [45]. Xinjiang is the largest cotton-producing province, and all cotton cultivation here depends on irrigation, which is blue water [46]. This leads to Xinjiang being the largest blue water-consuming region in the apparel manufacturing's supply chain. Planting cotton has caused some regions in China to experience a severe water crisis. Xinjiang is a typical arid area where the annual precipitation is only $50-250 \mathrm{~mm}$, but the evaporation amount is more than four times its precipitation [47]. Therefore, it is necessary to improve the irrigation efficiency of planting sectors. It can significantly improve the supply chain's overall water-use efficiency, reduce water consumption, and improve water productivity. In addition, the agricultural sector is also the largest generator of grey water. It discharges a large amount of grey water during production. Reducing water pollution from the agricultural sector is an effective measure to improve the water sustainability of apparel manufacturing.

Judging from the results in Figure 1, the sectors of apparel manufacturing, textile manufacturing, and chemicals production are also major dischargers of grey water. These sectors should implement stricter wastewater discharge standards and improve wastewater treatment capabilities. This can speed up the entire supply chain to achieve sustainable development of water resources.

It is meaningful to analyze the water problem from an interregional perspective. Our research reveals the distribution of blue water and gray water among 31 regions in China. The results show that the major contributor of apparel manufacturing is not necessarily the area most affected by water consumption and pollution. In China, each province plays a different role in the entire supply chain. The eastern coastal area headed by Guangdong is the primary output region of the apparel industry. However, its upstream sectors, such as fiber planting, are mainly concentrated in Xinjiang and Jiangsu. These regions usually consume large amounts of blue water, due to the heavy production tasks. Textile processing and chemical production are downstream of the planting sector. Shandong, Hebei and Henan mainly complete these processes. Therefore, their water pollution problems are more severe.

Furthermore, we applied the MRIO model to deeply analyze the spatial transfer pattern of blue and grey water among 31 regions. As the province with the largest apparel output, the industry development in Guangdong mainly depends on the support of other regions. The cotton supply in Xinjiang and Jiangsu eases the blue water pressure in Guangdong, and the textile manufacturing and processing in Hebei and Shandong also alleviate the gray water discharge. Analyzing the water transfer pattern of the industry from an interregional perspective can reveal the hidden linkage of water resources in China's apparel manufacturing. This can help policymakers to formulate a targeted recommendation. For example, the major exporters of blue water should improve wateruse efficiency to reduce water outflows. The major dischargers of grey water should improve their wastewater treatment capacity and prevent further polluting other regions. The regions such as Guangdong, which rely on foreign resources to develop their apparel 
industry, should rationalize their industrial structure to avoid further exacerbating water depletion and water pollution problems in other regions.

Understanding the spatial transfer of blue and grey water is also informative for water risk analysis. Assessing and monitoring the wastewater-related risk is vital to ensure the sustainable operation of the entire manufacturing facility [48]. This study indicates that "water risk" can spread and transfer among regions. For instance, in the life-cycle supply chain of China's apparel manufacturing, the COD-pollution-related risk is transferred from Guangdong to Hebei, Jiangsu, etc. Thus, the spatial transfer of "water risk" is suggested to be considered and integrated into future studies of water risk.

Increasing the water cost is a potential way to reduce water consumption and pollution effectively. China's government is pushing tiered pricing for industrial water users, i.e., the greater the water use, the higher the marginal water price. By doing this, those waterintensive factories are charged high prices for water use, and consequently, they have a strong motivation to reduce their water consumption as much as possible. Those industrial producers are also asked to ensure that their discharged water pollutants are within the allowed limits; otherwise, they will be fined.

However, the water pricing of the agricultural sector is quite different from that of the industrial sector in China. Currently, China's agricultural producers can use the water resources at a very low cost (even at no cost in some regions) because (1) the government supports farmers' incomes, (2) the food production cost is strongly related to food security, and (3) water use and pollution at farms sometimes are very hard to monitor. According to this study's results, as shown in Figure 1, most water consumption and pollution originate from the agricultural sector, i.e., fiber crops planting. Thus, China's government is strongly suggested to design an appropriate water pricing policy for the agricultural sector, especially for water-intensive crops, such as cotton, to mitigate its water crisis.

This study did not perform a comprehensive water cost analysis and, therefore, is unable to provide the water-pricing-related policy implications, which is the limitation of this study. Therefore, we encourage further studies to examine how to design an appropriate water-pricing policy to help mitigate the water stress induced by apparel manufacturing.

\section{Conclusions}

Water consumption and water pollution in apparel manufacturing impose a significant burden on the environment in China. This study employed an MRIO model to account for blue and grey water in the apparel sector in China in 2015 and analyze the sectoral transfer and spatial flow patterns of water. The results show that the agricultural sector was the main water-consuming and water-polluting sector. It consumed $87.43 \%$ of the total blue water and $49.12 \%$ of the total grey water. Thus, it is imperative to increase the wateruse efficiency in irrigation and reduce water pollution. Meanwhile, different provinces play different roles in the whole supply chain. The regions with high output values were mainly concentrated in Guangdong, Fujian and Jiangsu, while upstream industries, such as fiber cultivation and textile manufacturing, with high water consumption and pollution, were primarily concentrated in Xinjiang, Shandong, and Hebei. Xinjiang exported the most blue water $\left(2.66 \mathrm{Gm}^{3}\right)$, occupying $19.15 \%$ of the total blue water transfer in apparel manufacturing, while Shandong and Hebei discharged the most grey water, with $20.17 \mathrm{Gm}^{3}$ and $13.39 \mathrm{Gm}^{3}$. As the largest receiver of blue and grey water, Guangdong consumed a large amount of blue water from other regions and transferred massive grey water to other provinces. Although the environmental burden of Guangdong is primarily relieved by Xinjiang, Hebei and other regions, it also reflects that the development of apparel manufacturing in Guangdong is closely dependent on other regions. On the other hand, the regions such as Xinjiang, Heilongjiang and Hebei, the major water generator, will further increase their environmental burden and cause local water shortage and water pollution.

Our study has revealed the transfer of water resources throughout the supply chain in apparel manufacturing from an interregional and intersectoral perspective. Identifying the source of water consumption and pollution is the key point to solve the environmental 
problem. Furthermore, improving water-use efficiency and pollution control capacity will help the sustainable development of apparel manufacturing. More importantly, a reasonable industrial layout should be performed, according to the hidden linkage and use of resources in each region rationally to avoid aggravating environmental problems.

Author Contributions: Conceptualization, L.C. and A.L.; methodology, L.C. and A.L.; formal analysis, A.L.; investigation, A.L.; writing—original draft preparation, A.L. and A.H.; writing-review and editing, L.C.; visualization, A.H. and L.C.; supervision, L.C. All authors have read and agreed to the published version of the manuscript.

Funding: This work was supported by Beijing Natural Science Foundation (9204027) and the National training program of innovation and entrepreneurship for undergraduates (202110019091).

Institutional Review Board Statement: Not applicable.

Informed Consent Statement: Not applicable.

Conflicts of Interest: The authors declare no conflict of interest.

\section{References}

1. Karandish, F.; Šimůnek, J. An application of the water footprint assessment to optimize production of crops irrigated with saline water: A scenario assessment with HYDRUS. Agric. Water Manag. 2018, 208, 67-82. [CrossRef]

2. The United Nations World Water Development. Managing Water under Uncertainty and Risk, The United Nations World Water Development Report 4, UN Water Reports; World Water Assessment Programme: Paris, France, 2012.

3. Chen, F.; Ji, X.; Chu, J.; Xu, P.; Wang, L. A review: Life cycle assessment of cotton textiles. Ind. Textila 2021, 72, 19-29. [CrossRef]

4. Chen, L.; Wang, L.; Wu, X.; Ding, X. A process-level water conservation and pollution control performance evaluation tool of cleaner production technology in textile industry. J. Clean. Prod. 2017, 143, 1137-1143. [CrossRef]

5. Hossain, L.; Khan, M.S. Water Footprint Management for Sustainable Growth in the Bangladesh Apparel Sector. Water 2020, 12, 2760. [CrossRef]

6. Haque, F.; Khandaker, M.R.; Chakraborty, R.; Khan, M.S. Identifying Practices and Prospects of Chemical Safety and Security in the Bangladesh Textiles Sector. J. Chem. Educ. 2020, 97, 1747-1755. [CrossRef]

7. Dey, S.; Islam, A. A review on textile wastewater characterization in Bangladesh. Resour. Environ. 2015, 5, 15-44.

8. World Trade Organization (WTO) International Trade Statistics. Available online: https://data.wto.org/ (accessed on 14 June 2021).

9. Li, X.; Ren, J.; Wu, Z.; Wu, X.; Ding, X. Development of a novel process-level water footprint assessment for textile production based on modularity. J. Clean. Prod. 2021, 291, 125884. [CrossRef]

10. Ministry of Environental Protection of People's Republic of China (MEPPRC). Annual Statistic Report on Environment in China (2015); China Environmental Science Press: Beijing, China, 2016.

11. Parisi, M.L.; Fatarella, E.; Spinelli, D.; Pogni, R.; Basosi, R. Environmental impact assessment of an eco-efficient production for coloured textiles. J. Clean. Prod. 2015, 108, 514-524. [CrossRef]

12. Chapagain, A.; Hoekstra, A.; Savenije, H.; Gautam, R. The water footprint of cotton consumption: An assessment of the impact of worldwide consumption of cotton products on the water resources in the cotton producing countries. Ecol. Econ. 2006, 60, 186-203. [CrossRef]

13. Kazan, H.; Akgul, D.; Kerc, A. Life cycle assessment of cotton woven shirts and alternative manufacturing techniques. Clean Technol. Environ. Policy 2020, 22, 849-864. [CrossRef]

14. Liu, Y.; Zhu, L.; Zhang, C.; Ren, F.; Huang, H.; Liu, Z. Life cycle assessment of melange yarns from the manufacturer perspective. Int. J. Life Cycle Assess. 2019, 25, 588-599. [CrossRef]

15. Esteve-Turrillas, F.; de la Guardia, M. Environmental impact of Recover cotton in textile industry. Resour. Conserv. Recycl. 2017, 116, 107-115. [CrossRef]

16. Wiedemann, S.; Biggs, L.; Nebel, B.; Bauch, K.; Laitala, K.; Klepp, I.; Swan, P.; Watson, K. Environmental impacts associated with the production, use, and end-of-life of a woollen garment. Int. J. Life Cycle Assess. 2020, 25, 1486-1499. [CrossRef]

17. Yang, Y.; He, W.; Chen, F.; Wang, L. Water footprint assessment of silk apparel in China. J. Clean. Prod. 2020, $260,121050$. [CrossRef]

18. Hackett, T. A Comparative Life Cycle Assessment of Denim Jeans and a Cotton T-Shirt: The Production of Fast Fashion Essential Items from Cradle to Gate. Master's Thesis, University of Kentucky, Lexington, KY, USA, 2015.

19. Morita, A.M.; Moore, C.C.S.; Nogueira, A.R.; Kulay, L.; Ravagnani, M.A.D.S.S. Assessment of potential alternatives for improving environmental trouser jeans manufacturing performance in Brazil. J. Clean. Prod. 2020, 247, 119156. [CrossRef]

20. Hubacek, K.; Feng, K. Comparing apples and oranges: Some confusion about using and interpreting physical trade matrices versus multi-regional input-output analysis. Land Use Policy 2016, 50, 194-201. [CrossRef]

21. Schyns, J.F.; Hoekstra, A.Y.; Booij, M.J.; Hogeboom, R.; Mekonnen, M.M. Limits to the world's green water resources for food, feed, fiber, timber, and bioenergy. Proc. Natl. Acad. Sci. USA 2019, 116, 4893-4898. [CrossRef] [PubMed] 
22. Liao, X.; Chai, L.; Liang, Y. Income impacts on household consumption's grey water footprint in China. Sci. Total. Environ. 2021, 755, 142584. [CrossRef] [PubMed]

23. Su, B.; Ang, B. Multiplicative decomposition of aggregate carbon intensity change using input-output analysis. Appl. Energy 2015, 154, 13-20. [CrossRef]

24. Su, Y.; Liang, Y.; Chai, L.; Han, Z.; Ma, S.; Lyu, J.; Li, Z.; Yang, L. Water Degradation by China's Fossil Fuels Production: A Life Cycle Assessment Based on an Input-Output Model. Sustainability 2019, 11, 4130. [CrossRef]

25. Finogenova, N.; Dolganova, I.; Berger, M.; Nunez, M.; Blizniukova, D.; Müller-Frank, A.; Finkbeiner, M. Water footprint of German agricultural imports: Local impacts due to global trade flows in a fifteen-year perspective. Sci. Total. Environ. 2019, 662, 521-529. [CrossRef]

26. Salmoral, G.; Yan, X. Food-energy-water nexus: A life cycle analysis on virtual water and embodied energy in food consumption in the Tamar catchment, UK. Resour. Conserv. Recycl. 2018, 133, 320-330. [CrossRef]

27. Cai, B.F.; Mao, X.Q.; Wang, J.N.; Wang, M.D. Fine Resolution Carbon Dioxide Emission Gridded Data and their Application for China. J. Environ. Inform. 2018, 33, 82-95. [CrossRef]

28. Lenzen, M.; Moran, D.; Kanemoto, K.; Geschke, A. Building eora: A global multi-region input-output database at high country and sector resolution. Econ. Syst. Res. 2013, 25, 20-49. [CrossRef]

29. Dietzenbacher, E.; Los, B.; Stehrer, R.; Timmer, M.; De Vries, G. The construction of world input-output tables in the wiod project. Econ. Syst. Res. 2013, 25, 71-98. [CrossRef]

30. Giljum, S.; Wieland, H.; Lutter, S.; Bruckner, M.; Wood, R.; Tukker, A.; Stadler, K. Identifying priority areas for European resource policies: A MRIO-based material footprint assessment. J. Econ. Struct. 2016, 5, 99. [CrossRef]

31. Giljum, S.; Wieland, H.; Lutter, S.; Eisenmenger, N.; Schandl, H.; Owen, A. The impacts of data deviations between MRIO models on material footprints: A comparison of EXIOBASE, Eora, and ICIO. J. Ind. Ecol. 2018, 23, 946-958. [CrossRef]

32. Cabernard, L.; Pfister, S.; Hellweg, S. A new method for analyzing sustainability performance of global supply chains and its application to material resources. Sci. Total. Environ. 2019, 684, 164-177. [CrossRef]

33. Liu, H.; Liu, W.; Fan, X.; Liu, Z. Carbon emissions embodied in value added chains in China. J. Clean. Prod. 2015, 103, 362-370. [CrossRef]

34. Pan, W.; Pan, W.; Shi, Y.; Liu, S.; He, B.; Hu, C.; Tu, H.; Xiong, J.; Yu, D. China's inter-regional carbon emissions: An input-output analysis under considering national economic strategy. J. Clean. Prod. 2018, 197, 794-803. [CrossRef]

35. Han, M.; Li, S. Transfer Patterns and Drivers of Embodied Agricultural Land within China: Based on Multi-Regional Decomposition Analysis. Land 2021, 10, 213. [CrossRef]

36. Liao, X.; Chai, L.; Xu, X.; Lu, Q.; Ji, J. Grey water footprint and interprovincial virtual grey water transfers for China's final electricity demands. J. Clean. Prod. 2019, 227, 111-118. [CrossRef]

37. Aldaya, M.M.; Chapagain, A.K.; Hoekstra, A.Y.; Mekonnen, M.M. The Water Footprint Assessment Manual; Routledge: London, UK, 2012. [CrossRef]

38. Chai, L.; Han, Z.; Liang, Y.; Su, Y.; Huang, G. Understanding the blue water footprint of households in China from a perspective of consumption expenditure. J. Clean. Prod. 2020, 262, 121321. [CrossRef]

39. Chai, L.; Liao, X.; Yang, L.; Yan, X. Assessing life cycle water use and pollution of coal-fired power generation in China using input-output analysis. Appl. Energy 2018, 231, 951-958. [CrossRef]

40. Guan, D.; Hubacek, K.; Tillotson, M.; Zhao, H.; Liu, W.; Liu, Z.; Liang, S. Lifting China's Water Spell. Environ. Sci. Technol. 2014, 48, 11048-11056. [CrossRef]

41. Guo, X.; Ho, M.S.; You, L.; Cao, J.; Fang, Y.; Tu, T.; Hong, Y. Industrial Water Pollution Discharge Taxes in China: A Multi-Sector Dynamic Analysis. Water 2018, 10, 1742. [CrossRef]

42. Zhao, X.; Liu, J.; Liu, Q.; Tillotson, M.; Guan, D.; Hubacek, K. Physical and virtual water transfers for regional water stress alleviation in China. Proc. Natl. Acad. Sci. USA 2015, 112, 1031-1035. [CrossRef]

43. Zheng, H.; Zhang, Z.; Wei, W.; Song, M.; Dietzenbacher, E.; Wang, X.; Meng, J.; Shan, Y.; Ou, J.; Guan, D. Regional determinants of China's consumption-based emissions in the economic transition. Environ. Res. Lett. 2020, 15, 074001. [CrossRef]

44. Yu, S.X.; Zhang, L.; Feng, W.J. Easy and enjoyable cotton cultivation: Developments in China's cotton production. Cotton Sci. 2015, 3, 283-290.

45. Li, N.; Li, Y.; Biswas, A.; Wang, J.; Dong, H.; Chen, J.; Liu, C.; Fan, X. Impact of climate change and crop management on cotton phenology based on statistical analysis in the main-cotton-planting areas of China. J. Clean. Prod. 2021, 298, 126750. [CrossRef]

46. Zhang, L.; van der Werf, W.; Cao, W.; Li, B.; Pan, X.; Spiertz, J. Development and validation of SUCROS-Cotton: A potential crop growth simulation model for cotton. NJAS Wagening. J. Life Sci. 2008, 56, 59-83. [CrossRef]

47. Wang, Z.; Fan, B.; Guo, L. Soil salinization after long-term mulched drip irrigation poses a potential risk to agricultural sustainability. Eur. J. Soil Sci. 2019, 70, 20-24. [CrossRef]

48. Trubetskaya, A.; Horan, W.; Conheady, P.; Stockil, K.; Merritt, S.; Moore, S. A methodology for assessing and monitoring risk in the industrial wastewater sector. Water Resour. Ind. 2021, 25, 100146. [CrossRef] 